\title{
DECREASING WORK-RELATED PESTICIDE EXPOSURES AMONG FARMERS AND THEIR FAMILIES IN WADI EL-MULLAK VILLAGE, SHARKIA GOVERNORATE, EGYPT (AN INTERVENTIONAL STUDY).
}

\author{
By \\ Zalat MM, Abo El-Seoud AR and Rabie SM \\ Department of Community, Environmental and Occupational Medicine,
} Faculty of Medicine, Zagazig University, Egypt.

\begin{abstract}
Introduction: Pesticides, pesticide products and related chemicals have been found to have a wide range of health effects. Many farmers' activities pose serious risks of pesticide exposure, such as land preparation for cultivation, storing, mixing, preparing and spraying of pesticide, loading and cleaning of spraying equipment. Farmers' knowledge and perception about pesticide risks play an important role in determining the use of pesticides protective device. Aim of Work: (1) To assess knowledge of farmers, their families toward pesticide use and pesticide hazards in Wadi El Mullak village (2) To assess safe pesticide use behavior (3) To evaluate the effect of health education program on their knowledge, attitude toward pesticides exposure. Materials and Methods: This study was conducted through two phases (a cross- sectional study, and an intervention educational program) among farmers living in EL-Mullak village for at least 3 months from the time of interview, participants of the cross sectional phase were $(n=202)$, were satisfying the inclusion criteria. An interviewer questionnaire was filled before and after the health education intervention program, a checklist was also utilized to determine the actual practices of the respondents in the field before and after the intervention. Results: (1) there are a significant relation between farmers' educational level and their level of knowledge (2) there is a statistically highly significant effect of health education of the intervention program on farmers' knowledge of safety behaviors
\end{abstract}


associated with pesticide use (3) there is significant relation between receiving previous training on pesticides issues and decreased appearance of symptoms. Conclusion and Recommendations: This study concludes that health education and proper training are effective forms of intervention in improving the knowledge, attitude and practices of farmers on the use of pesticide.

Key words: Pesticides; Farmers; Knowledge; Awareness; and Safety behavior.

\section{Introduction}

A pesticide is generally a chemical or biological agent (such as a virus, bacterium, antimicrobial or disinfectant) that through its effect deters, incapacitates, kills or otherwise discourages pests (Gilden et al., 2010). Human exposure to pesticides may occur through occupational exposure in the case of agricultural workers in open fields and greenhouses, workers in the pesticide industry, and exterminators of house pests (Martinez et al., 2009).

Moreover, individuals can be exposed during the preparation and application of pesticides or even after the applications are completed, whereas delayed exposure can occur through inhalation of residual air concentrations or exposure to residues found on surfaces, clothing, bedding, food, dust, discarded pesticide containers, or application equipment (Eleftherohorinos, 2008; Karabelas et al., 2009; Pimentel et al., 2011).
Pesticide exposure can cause a variety of adverse health effects, ranging from simple irritation of the skin and eyes to more severe effects such as affecting the nervous system, mimicking hormones causing reproductive problems, and also causing cancer (EPA, 2012).

Jeyaratnam, 2000, reported in his study, that as many as 25 million workers in developing countries may suffer mild pesticide poisoning yearly. The World Health Organization and the UN Environment Programme estimate that each year, 3 million workers in agriculture in the developing world experience severe poisoning from pesticides, about 18,000 of whom die (Miller, 2004]).

Risk assessment of pesticide impact on human health is not an easy and particularly accurate process because of differences in the periods and the levels of exposure,type of pesticides (regarding toxicity), mixtures or cocktails used in the field, and the geographic and 
meteorological characteristics of the agricultural areas where pesticides are applied (Bologensi, 2003). Pesticides, pesticide products and related chemicals have been found to have a wide range of health effects. They include: mutagenic substances, carcinogens or probable carcinogens, endocrine disrupters, reproductive toxic substances and neurotoxin substances (Sanborn et al., 2007). Concerning neoplasm, it was found that pesticides associated with changes in hematopoiesis and chromosomes of the cells that can progress to myelo dysplastic syndrome or myeloid leukemia and non-Hodgkin's lymphoma (Miligi et al., 2006). In 2007, a systematic review found that "most studies on non-Hodgkin lymphoma and leukemia showed positive associations with pesticide exposure" and thus concluded that cosmetic use of pesticides should be decreased (Baris et al., 2007).

In Wadi El Mullak village in Sharkia Governate, the types of cancer that have most commonly been linked with occupational exposures and for which evidence is strong, are those of the lung, urinary bladder, mesothelioma, larynx, leukaemia, angiosarcoma of the liver, nose and nasal cavity and skin non -Hodgkin lymphoma and leukemia (Abou El khair et al., 2012). Farmer's knowledge and perception about pesticide risks play an important role in determining the use of pesticides protective device (Mekonnen and Agonafir, 2002).

Agricultural scientists started to develop alternative crop management systems to minimize the negative effects of farming (based mainly on pesticide use for crop protection) to the environment and to human health. In particular the Integrated Crop Management (ICM) includes guidelines to be used by the farmer unions to enforce actions for production of safe agricultural products with simultaneous respect to the environment (Nwilene et al., 2008). ICM includes measures for implementation of good agricultural practices (GAP), the safety and hygiene of workers, the safety of the products, the full traceability of the measurements, and specific actions for the preservation of the environment (Chandler et al., 2008). For the control of pests, ICM encourages the use of complementary methods of pest management (such as crop resistance against insects and 
fungi, biological control, and other cultural or physical measures) to reduce the animal pest or weed population below its economic injury level and to minimize pesticide impacts on other components of the agro-ecosystem (Way and Van, 2000).

In Egypt In 1970, Central Agricultural Pesticides Laboratory (CAPL) was established according to an agreement between the Egyptian government and Food and Agriculture Organization (FAO) in 1959. The purpose was to regulate pesticide use in Egypt by covering the different activities of agricultural pesticides and fulfilling the registration requirement in addition to offering the technical help in field of pesticides use and disseminating information about the wise use of pesticides throughout the region, (Central Agricultural Pesticides Laboratory, 2009).

Also, The CAPL attempts to bring imported and exported pesticides under stringent control. The purpose is to prevent pesticides which do not comply with Egyptian regulations from reaching the end user. At the time pesticides enter importation status, they are examined in the CAPL (Central Agricultural Pesticides Laboratory, 2009).

\section{Aim of Work}

The goal of this study is to decrease the work-related Pesticide Exposures among Farmers and their Families in Wadi El-Mullak Village, Sharkia Governorate. Our objectives were:

1. To assess knowledge of farmers, their families toward pesticide use, pesticide hazards in Wadi El-Mullak Village, Sharkia Governorate.

2. To assess safe pesticide use behavior.

3. To evaluate the effect of health education on their knowledge, attitude toward pesticides exposure.

\section{Materials and Methods}

\section{Study design and setting:}

This study was carried out during the period from April through August 2013 in the main Family Health Center in Wadi El-Mullak Village, Sharkia Governorate through two phases.

Phase I: A cross- sectional study, and Phase II: An intervention educational program.

\section{Study sample:}

The sample size was estimated randomly using change in safety 
behavior from $55 \%$ to $77 \%$ at $95 \%$ confidence interval and $80 \%$ power of test using Epi-info (Epidemiological Information Package) software program version 6 . The sample size calculated was 252 individuals (almost 50 families) assuming that each family contain 5 individuals, two hundred and twenty individuals $(n=220)$, were satisfying the inclusion criteria. Only two hundred and two individuals accepted the participation in the study with response rate $91 \%$. Fifty families were selected by systemic random selection from village houses.

\section{Study Population}

Farm workers and their families in Wadi El-Mullak Village, Sharkia Governorate.

\section{Inclusion criteria}

Farmers who living in EL-Mullak village for at least one year before the interview, and practicing farmers who own or work as farmers in the village.

\section{Exclusion criteria:}

Those who have been in the area for less than 3 months, migrant farmers and those included in the pilot study were excluded from the study.

\section{IV.Study Methods}

\section{A. Data collection:}

\section{Phase I}

A structured interviewed questionnaire was used for interviewing of the farmers and their families with cooperation of village leaders and health visitor nurses who facilitated entrance of researchers into farmer houses and assisted the communication when it was necessary.

\section{There were four sections in the} questionnaire:

1. The first was the socio-demographic characteristics of the studied individuals which contain questions regarding age, gender, marital status, educational level, and job duration.

2. The second section was consisted of questions related to the occupational characteristics as the types of crops cultivated; activities associated with pesticides application and utilization practices such as formulation, spraying and storage of pesticides.

3. The third section consisted of pesticides knowledge questions 
about benefits, harmful effects, and utilization of pesticides.

4. The last section included questions about the symptoms of pesticides poisoning such as irritation, nausea, vomiting, chest tightness, headaches and dizziness.

- The pre /post questionnaire including behavior questions on activities associated with pesticides application (safety knowledge, application methods, application time, self-protection methods used, and other behavioral risk factors) were based on the world health organization reports (WHO, 1985; WHO, 1991) concerning pesticide use in agriculture.

\section{Phase II (The interventional educational program)}

The farmers and their families were exposed to an educational program which includes the following items:

\section{a- Health education:}

The purpose of the educational session was to give the sound knowledge about types of pesticides, routes of exposures, symptoms of pesticides poisoning, first aid for pesticides exposure, and safe pesticide behaviors on (application methods, application time, disposal, storage, and self-protection methods).

The educational session was given in the family health center and agriculture unit in the village for the farmers and their families in small groups by direct face to face communication as lectures aided by uses of posters, figures, and small group discussion. Together with the educational session, sometimes protective gloves, educational booklet were freely given to the farmers.

The researchers visited the village five times, three times for pre-test and health education program application and after 3 months, went other two times for post-test and evaluating the effect of educational intervention on their knowledge and behavior.

In every visit the researchers met a group formed of about 15 to 17 families. Every group were seen twice the first meeting for pre-test and health education program intervention it lasted about 4 hours and the second meeting was prepared for post-test application it lasted for 2 hours. The researchers invited the participants to the family health unit and agricultural unit by mosque. Visited other participants in 
their homes. The researchers gave the participants facemasks and posters as a gift.

\section{Scoring of knowledge;}

Each right answer is given 1 score, wrong answer is given zero score. Total score is 17 .

If the farmers score is $<9$ his knowledge is considered un-satisfactory.

If his score 9-13 his knowledge is satisfactory.

If his score 14-17 his knowledge is very good.

\section{b.Sound occupational health practice:}

Practical instructions were given by using educational posters regarding special precautions when using pesticides and first aid for pesticides poisoning. After the health education, post-test questionnaire was done for the study subjects after period of about three months to evaluate the effect of health education program on their safety knowledge with pesticides usage.

\section{B- Pilot study:}

A pilot study was done on 10 farmers before the main study. Some changes were done to the questionnaire following the pilot study to improve clarity and convenience. These 10 farmers were not included in the main survey.

\section{Data management:}

The collected data were presented, summarized, tabulated \& analyzed by using computerized Statistical Package of Social Science (SPSS) version 19 (IBM, 2010).

Quantitative data were represented as arithmetic means and standard deviations (X \pm SD) (Feinstein, 2002). Qualitative data were represented as frequencies and percent, Chi-square test $(\chi 2)$ was carried out for calculating significant differences between the qualitative data (Forthofer, and Lee, 1995). A result was considered statistically significant when the significant probability was less than $0.05(\mathrm{P}<0.05)$.

\section{Ethical Approval:}

Proposal acceptance was obtained from the Institutional Review Board (IRB) of the Faculty of Medicine; Zagazig University. Ethical considerations and confidentiality were respected. 


\section{Consent:}

An informed consent was obtained from all participants of this study. The farmers were told about the aim of the study, and they were informed that the data are confidential and will be used for scientific purposes only. The farmers were also given the right to refuse or participate in the study.

\section{Results}

Socio-demographic characteristics of the farmers at Wadi el Mullak village showed that the mean age of the study participants was $38.3 \pm 16.1,78.7 \%$ of them range from 20-60 years. Sixty five
$\%$ of the participants were male, $83.7 \%$ married, and $44.1 \%$ were working as farmers only while, and $55.9 \%$ had other occupation besides being farmers. Most of the farmers were illiterate or had moderate education $(41.1 \%$ and $36.6 \%$ respectively). The mean family size was $2.3 \pm 0.4$ and majority of family number ranged from 3-6 person (63.6\%). Regarding the crops cultivated in the study area, maize is produced by (20\%) followed by wheat (19.8\%), fruit (15.4\%), vegetables (13.8\%) and about $31 \%$ grown other crops like potato. lemon and clover. 
Table (1): Pesticides practices and occupational exposure data of farmers and their families in Wadi El Mullak village, 2013.

\begin{tabular}{|c|c|c|}
\hline & Total no (202) & $\%$ \\
\hline $\begin{array}{l}\text { Pesticide applier (sprayer): } \\
\text { Farmer himself } \\
\text { Family member } \\
\text { Hired labor }\end{array}$ & $\begin{array}{l}49 \\
79 \\
74\end{array}$ & $\begin{array}{l}24.3 \\
39.1 \\
36.6\end{array}$ \\
\hline $\begin{array}{l}\text { Pesticide formulation used: } \\
\text {-Dust or powder } \\
\text {-Liquid spray } \\
\text {-Granules } \\
\text {-others }\end{array}$ & $\begin{array}{c}\text { Total no }(\mathbf{3 7 3}) \\
195 \\
178 \\
0 \\
0\end{array}$ & $\begin{array}{c}\mathbf{1 0 0 \%} \\
52.3 \\
47.7 \\
0.0 \\
0.0\end{array}$ \\
\hline Using Pesticide without label & 28 & 13.9 \\
\hline Using Pesticide with unknown language & 41 & 20.3 \\
\hline Received training for pesticides usage & 37 & 18.3 \\
\hline Keeping livestock at home & 187 & 92.6 \\
\hline Using pesticide on livestock & 54 & 26.7 \\
\hline $\begin{array}{l}\text { Pesticides storage: } \\
\text {-Kitchen } \\
\text {-Separate place (in house) } \\
\text {-others (outside house) }\end{array}$ & $\begin{array}{c}1 \\
166 \\
35\end{array}$ & $\begin{array}{c}0.5 \\
82.2 \\
17.3 \\
\end{array}$ \\
\hline $\begin{array}{l}\text { Fate of empty containers: } \\
\text { Reuse } \\
\text { Sold } \\
\text { Dispose } \\
\text { others }\end{array}$ & $\begin{array}{c}38 \\
0 \\
107 \\
84\end{array}$ & $\begin{array}{l}18.8 \\
0.0 \\
53.0 \\
41.6\end{array}$ \\
\hline $\begin{array}{l}\text { Job duration (years) } \\
\text { Mean } \pm \text { SD }\end{array}$ & $25.2 \pm 15.2$ & \\
\hline
\end{tabular}

Other pesticide as; Oxicarbamate, Ridomil, Diathin,Thionex and so4.Other places of pesticide place; in special room in the filed or in special room beside the house. 
Table (1) shows data about pesticides practices and occupational exposure among farmers and their families in Wadi El Mullak Village. The mean job duration was $25.2 \pm 15.2$ years. Pesticide application was done by family member $(39.1 \%)$ or by hired labors $(36.6 \%)$, or by the farmer himself $(24.3 \%)$, and majority of farmers $(52.3 \%)$ applied pesticide in dust or powder form. About $20.3 \%$ of the participants used pesticide with unknown language, whereas $13.9 \%$ used it without label. Only $18.3 \%$ of the study subjects received training for pesticides usage before. About $92.6 \%$ of farmers were keeping livestock at home and $26.7 \%$ of them were using pesticide on livestock. Eighty two percent of the participants stored pesticide at separate place inside the house. About 18.8\% of the participants reuse the empty containers of pesticide while, $53 \%$ of them were disposed it.

The majority of the farmers $(82.2 \%)$ stored their pesticide in a separate place specified for pesticides storage. Pesticides used for many purposes as insecticide $(18.3 \%)$, fungicide $(8.9 \%)$, rodenticide $(2.5 \%)$, and most of them (70.3\%) used for more than one purpose.

Concerning, knowledge of the farmers about pesticide usage. The results shows that the percent of correct answers among the whole sample was high about storage of pesticides away from food $(95.2 \%)$, pesticides can't be kept with fertilizer $(87.1 \%)$, and they also know the harmful effect of pesticides on consumer and environment (78.7 \%, 78.2\% respectively). 


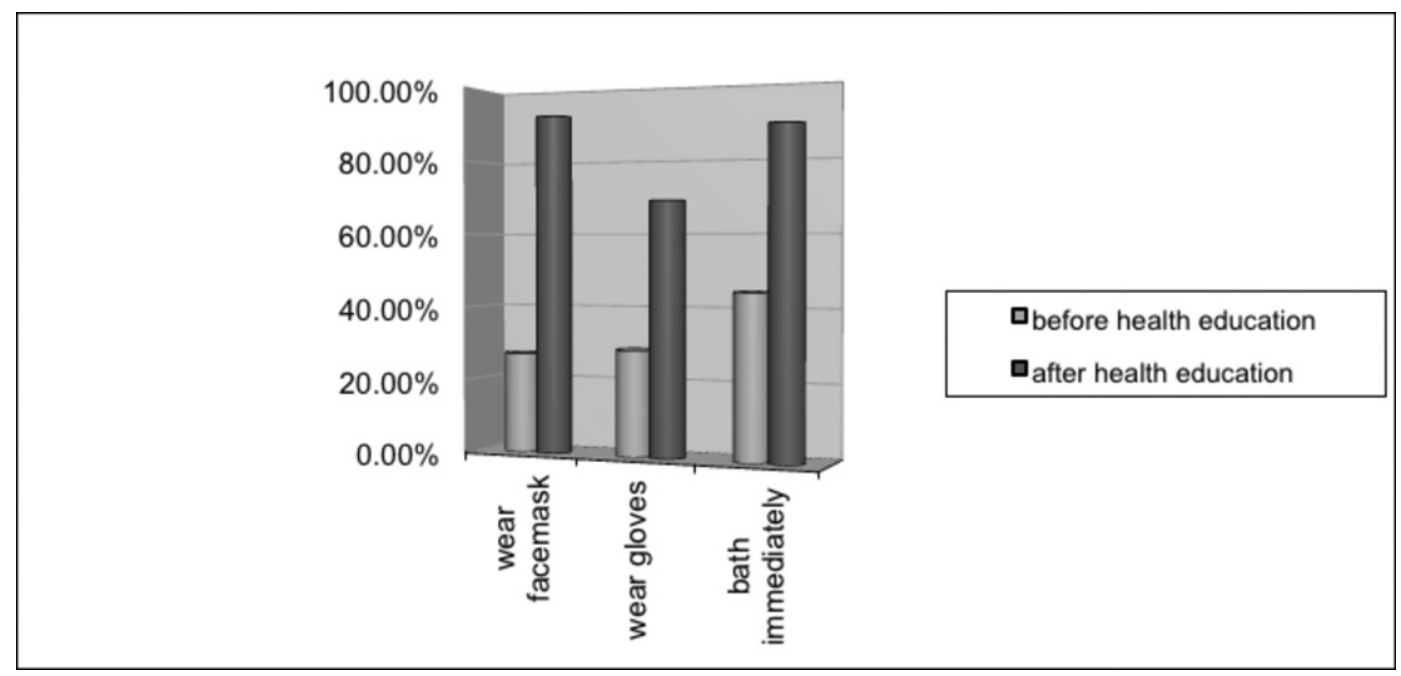

Figure (1) Major change in knowledge of safety behavior before and after health education.

Figure (1) demonstrated higher proportions of change in knowledge of safety behavior which occurred after application of health education especially in knowledge of wearing facemask, wearing gloves, bathe immediately, wearing long boots, wearing long sleeves and avoid eye rubbing. 


\section{symptoms of self-reported pesticides poisoning}

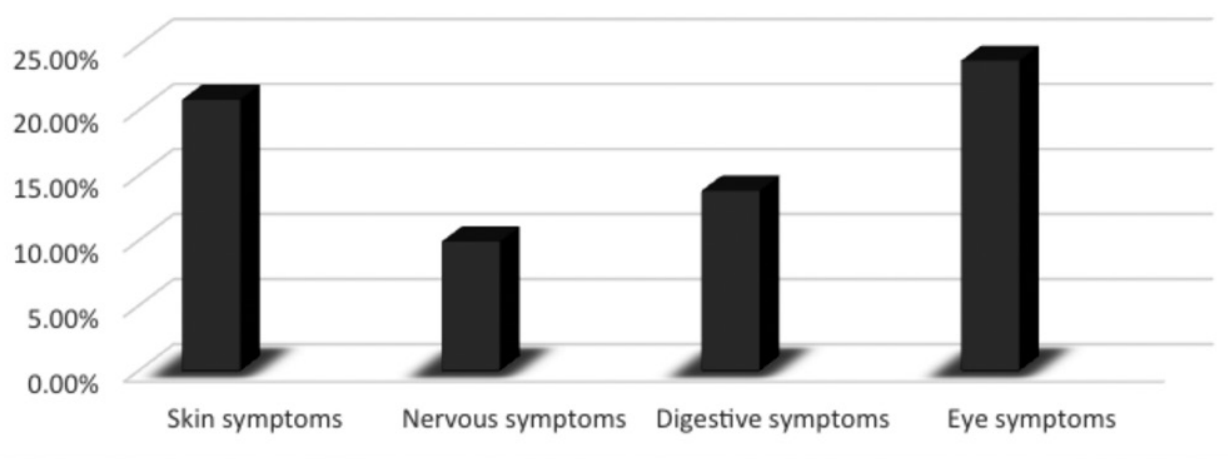

Figure (2): List of symptoms of pesticide poisoning self -reported by the pesticides applicators in Wadi El Mollak village, 2013.

Figure (2) shows list of symptoms of pesticide poisoning reported by 138 participants after pesticide application. The most frequent symptoms suffered by pesticides applicators were related to eye (23.8\%), skin (20.8\%) followed by gastrointestinal symptoms (13.8\%), whereas symptoms related to nervous symptoms were low $(9.9 \%)$. 
Table (2): Relationship between socio-demographic characteristics and adequate knowledge of workers after health education intervention.

\begin{tabular}{|c|c|c|c|c|c|c|}
\hline \multirow[t]{2}{*}{ Variable } & \multicolumn{2}{|c|}{$\begin{array}{c}\text { Inadequate } \\
(\mathbf{n}=29)\end{array}$} & \multicolumn{2}{|c|}{$\begin{array}{l}\text { Adequate } \\
(\mathbf{n}=173)\end{array}$} & \multirow[t]{2}{*}{$\chi 2$ test } & \multirow[t]{2}{*}{ P value } \\
\hline & $\mathbf{N}$ & $\%$ & $\mathbf{N}$ & $\%$ & & \\
\hline $\begin{array}{l}\text { Age (years) } \\
<20 \\
20-60 \\
>60\end{array}$ & $\begin{array}{l}4 \\
24 \\
1 \\
\end{array}$ & $\begin{array}{r}13.79 \% \\
82.76 \% \\
3.45 \%\end{array}$ & $\begin{array}{l}27 \\
135 \\
11\end{array}$ & $\begin{array}{c}15.61 \% \\
78.03 \% \\
6.36 \% \\
\end{array}$ & 0.4 & 0.7 \\
\hline $\begin{array}{l}\text { Sex } \\
\text { Male } \\
\text { Female }\end{array}$ & $\begin{array}{l}14 \\
15\end{array}$ & $\begin{array}{l}48.23 \% \\
51.72 \%\end{array}$ & $\begin{array}{l}118 \\
55\end{array}$ & $\begin{array}{l}68.23 \% \\
31.77 \%\end{array}$ & 4.7 & 0.08 \\
\hline $\begin{array}{l}\text { Education } \\
\text { Illiterate } \\
\text { Read \&write } \\
\text { Moderate } \\
\text { Higher education }\end{array}$ & $\begin{array}{l}23 \\
4 \\
2 \\
0\end{array}$ & $\begin{array}{c}79.31 \% \\
13.79 \% \\
6.90 \% \\
0.0 \%\end{array}$ & $\begin{array}{c}60 \\
21 \\
72 \\
20\end{array}$ & $\begin{array}{c}34.68 \% \\
12.14 \% \\
41.62 \% \\
11.56 \%\end{array}$ & 23.6 & $0.0002^{*}$ \\
\hline $\begin{array}{l}\text { Martial } \\
\text { Married } \\
\text { Unmarried }\end{array}$ & $\begin{array}{l}25 \\
4\end{array}$ & $\begin{array}{l}86.21 \% \\
13.79 \%\end{array}$ & $\begin{array}{l}144 \\
29\end{array}$ & $\begin{array}{l}83.24 \% \\
16.76 \%\end{array}$ & 0.16 & 0.68 \\
\hline $\begin{array}{l}\text { Occupation } \\
\text { Farmers only } \\
\text { Farmers + other } \\
\text { occupation }\end{array}$ & $\begin{array}{l}15 \\
14\end{array}$ & $\begin{array}{l}51.72 \% \\
48.28 \%\end{array}$ & $\begin{array}{c}74 \\
99\end{array}$ & $\begin{array}{c}42.77 \% \\
57.23 \%\end{array}$ & 0.8 & 0.3 \\
\hline
\end{tabular}

Wrong answer $=0$, right answer $=1$, Score $\geq 9$ means adequate knowledge, Score $<9$ means inadequate knowledge

Table 2 shows the relationship between socio-demographic characteristics and adequate knowledge of workers after health education intervention. There are high level of adequate knowledge after application of health education among male, older age, higher education but without significant difference except for level of education which is highly significant $(\mathrm{p}<0.001)$. 
Table (3): Relationship between appearance of symptoms and training, gender of participants.

\begin{tabular}{|c|c|c|c|c|c|c|c|}
\hline \multirow{2}{*}{ Variable } & & \multicolumn{2}{|c|}{ Symptoms } & \multicolumn{2}{|c|}{ No symptoms } & \multirow{2}{*}{$\chi^{2}$ test } & \multirow{2}{*}{$P$ value } \\
\hline & & No & $\%$ & No & $\%$ & & \\
\hline \multirow[t]{2}{*}{ Training } & no & & 90.28 & 100 & 76.92 & \multirow{3}{*}{5.52} & \multirow{3}{*}{0.019} \\
\hline & Yes & 7 & 9.72 & 30 & 23.08 & & \\
\hline Total & & 72 & $100 \%$ & 130 & $100 \%$ & & \\
\hline \multirow[t]{2}{*}{ Sex } & Male & 43 & 59.72 & 89 & 68.46 & \multirow{3}{*}{2.3} & \multirow{3}{*}{0.31} \\
\hline & Female & 29 & 40.28 & 41 & 31.54 & & \\
\hline Total & & & 100 & 130 & 100 & & \\
\hline
\end{tabular}

Table 3 shows that there is significant relation between receiving training and decreased appearance of symptoms.

\section{Discussion}

The use of pesticides is currently the main pest management strategy to guarantee the World's food supply (Pasiani et al., 2012). In Egypt pesticides are extensively used for pest control in agriculture. Their usage and unsafe handling practices may potentially result in high farmer exposures and adverse health effects. In this study, 202 farmers in Wadi El Mullak village were interviewed to assess knowledge of farmers and their families toward pesticides exposure hazards and to evaluate the effect of health education program on their knowledge and attitude toward these hazards. Various sources of potential domestic and occupational pesticide exposure were noted during the survey.

Similar to many areas in Egypt, the most common crops cultivated in Wadi El Mullak village were maize, wheat, fruits and vegetables. These types of crops are planted since ancient times (Pharaonic) which are highly related to the soil of excellent quality near the Nile River and the Egyptian climate which is sunny and therefore conductive for growing these crops. 
About $92.1 \%$ of the participants were using pesticides occasionally. The pesticides used by the farmers included moderately hazardous WHO Class II products such as malathion (51\%) and DDT (43\%). Malathion is an organophosphate and dichlorodiphenyltrichloroethane (DDT) is an organochlorine pesticides banned in many countries for health and environmental concerns and have been included in the list of Persistent Organic Pollutants (POPs) scheduled for elimination (UNEP, 2009). Also, DDT is an endocrine disruptor that is considered likely to be a human carcinogen (Corriols et al., 2008).

Storage of pesticides in unguarded sites in residences is common in many developing countries (Kimani and Mwanthi, 1995, Murphy et al., 2002; Ngowi et al., 2002). In this study, most of the farmers $(82.1 \%)$ reported storing the pesticide products at separate place inside the house. However, most of these places were in unguarded accessible places.

The prevalence of unguarded domestic storage was higher in this study compared to previous study in Tanzania (68\%, 43\%) (Ngowi et al.,
2002), probably because respondents in the previous studies were informed of the researcher's visit, so had the time to rearrange the stored products before the visit. Moreover, about $53 \%$ of the empty containers of the pesticides used were disposed. This finding is in agreement with previous studies in Brazil (Bigatão, 2009) which reported that $34.8 \%$ of the farmers burned or buried the pesticide containers. On the other hand (Recena et al., 2006) found that $54.4 \%$ of farmers stored the empty containers in their homes which indicates that the best practices are, not fully carried out by these farmers.

Concerning farmer's knowledge, this study showed that the percent of correct answers among the whole sample was high regarding storage of pesticides away from food (95.2\%), pesticides can't be kept with fertilizer (87.1\%), and they also know the harmful effect of pesticides on consumer and environment (78.7\%, $78.2 \%$ respectively) similar to study conducted in (Recena et al., 2006).

Proper use and maintenance of protective clothing are considered important behaviors associated with reduced chemical exposures. In 
contrary to many studies conducted in many parts of the world like Ethiopia and Tanzania (Mekonnen and Agonafir, 2002;- Ngowi et al., 2002; Ngowia et al., 2007; Williamson et al., 2008; Hiluf and Ayalew, 2015) and another agricultural areas in Egypt (Tchounwou et al., 2002; Ibitayo, 2006) The results showed that the farmers participating in our study seemed to be relatively aware of the importance of Personal Protective Devices (PPDs), $62.9 \%$ of the farmers in our study wore hats, $51 \%$ of them wore boots, but less than half wore masks and gloves, which is consistent with study conducted in Brazil by (Recena et al., 2006). However, the possible reasons for not adequate using of PPD among the present sample could be due to unavailability of protective devices at governmental agricultural association and their high cost at private sector. Moreover, the hot weather was among the causes of low use of PDD as reported by studies conducted in USA (Rucker, 2004).

In this study, most of the farmers (61.4\%) reported that they follow the instructions present on the pesticide containers, which is contradictory to the results of the study conducted in
Ethiopia that found most of farmers didn>t read instructions on pesticides packages and attributed that to illiteracy or even the reluctance to read the written instructions (Mekonnen and Agonafir, 2002). Also, another study by Hiluf and Ayalew, (2015) reported that $41.67 \%$ of the respondents could read labels on pesticide containers, only $13.54 \%$ could understand and follow instructions whereas, $14.76 \%$ of them indicated that they had bought pesticides without labels.

In the current study, $55.4 \%$ of the farmers did not take a shower after pesticide application, $37.1 \%$ of them did not change clothes immediately and $13.9 \%$ of them did not wash their clothes used during pesticide spraying separately, and this will increase the chance that the farmers $>$ family members including children could be exposed to pesticides indirectly due to the takehome exposure or para-occupational exposure pathways which include returning home with working clothes, washing and cleaning contaminated clothes in the home laundry, mixing and storing pesticides at home and cleaning equipment used for application at home. In the last five years, $89.40 \%$ of the 
families of different study participants were poisoned and recovered, $7.82 \%$ had long term injuries and $2.78 \%$ died because of the poisoning incidence (Tsakiris et al., 2004, Nwilene et al., 2008). These findings were also consistent with other studies conducted among Palestinian farmers and in other parts of the world as Germany as confirmed in previous study by Burger et al., (2008).

In agreement with the study done by Recena et al.,) 2006) about $8.4 \%$ of participants reported smoking while applying pesticides and also $34.8 \%$ of them having a meal in the field. This increases their risk of exposure to pesticides.

The great majority of the farmers $(80.7 \%)$ observed the importance of knowing direction of wind and choosing the proper time of application. These practices are important to minimize human exposure to pesticide as confirmed previously by a study conducted by Silva et al., (2005).

Results of this study reported that the overall knowledge of the respondents highly increased after application of the intervention program. There was a statistically highly significant effect of health education intervention program on farmers' knowledge of safety behaviors associated with pesticide use. For example, wearing facemask, gloves, hats, and bathe immediately after pesticides application. Also, these findings are in agreement with study conducted by Sivayoganathan et al., (1995).

As regard the relationship between socio-demographic factors and adequate level of farmer's knowledge and their families after the health education. It was observed that older age, male gender, higher level of education affect the adequacy of their knowledge but without significant difference except for level of education which was highly significant $(\mathrm{p}<0.001)$. This result also confirmed the findings of the earlier studies indicating that there are a significant relation between farmers' educational level and their level of knowledge (Nazaril et al., 2011). This was also consistent with studies reporting that low education level limits the ability of farmers to fully understand all the health risks of pesticides and the importance of safety measures (Yassin et al., 2002). 
In addition, there was a significant relation between receiving previous training on pesticides issues and decreased appearance of symptoms $(p=0.01)$. This could be explained by the fact that receiving previous training provide more awareness for the safe use of pesticides, but there were no significant relation between pesticide type, sprayer, duration of spraying and appearing of symptom. This may be attributed to inadequate training in these points. Furthermore, the frequency and duration of pesticide handling both on a seasonal and lifetime basis affects the exposure. In particular, the exposure of an individual farmer that applies a pesticide once a year is lower than that of a commercial applicator that normally applies a pesticide for many consecutive days or weeks in a season (Karabelas et al., 2009).

\section{Conclusion}

Exposure to pesticides among farmers and farmers' families is a major health threat. This well-known fact is one obvious and important rational for safe handling and practices of pesticides. From the results of this study, it can be concluded that 1) farmers, their family members, in Wadi El Mullak village are both directly and indirectly exposed to highly hazardous, restricted, and banned pesticides with insufficient protection and safety precaution with regard to pesticide formulation and application; 2) substantial amounts of pesticides are inappropriately used by these farmers, leading to several clinic manifestations including eye, skin irritation, nausea, vomiting, abdominal cramps, headache, blurred vision, dizziness, excessive salivation, sweating and cancer in some cases; 3 ) health education and proper training are an effective form of intervention in improving the awareness of farmers on the hazardous use of pesticide.

\section{Recommendations}

Based on the study findings the following are recommended as summary:

1. Farmers are in need for health education and training programs to provide them with detailed instructions about safety precautions that must be taken during pesticide formulation and application.

2. Providing personal protective devices for farmers with reasonable prices taken to encourage them to take safety precautions. 
3. Used containers of pesticide issues can be collected for reduced prices to decrease unsafe disposal.

4. There should be re-evaluation of actual practices of farmers in using pesticides one year after the intervention in Wadi El Mullak village.

5. There should be an integrated effort from governmental and nongovernmental organizations that focus on the awareness raising of farmers on proper pesticide management and related issues in other governorates in Egypt. Additionally, a laboratory based study (residual analysis of blood, soil and water) is recommended so that the extent of pesticide damage on public health and the environment could be evaluated.

\section{Conflict of interests}

Authors have declared that no conflict of interests exists.

\section{References}

1. Abou El khair M, Zalat MM, Salem GM and Awad Allah MB (2014): Studying the evidence of complexity of interaction between environmental, occupational and host cancer risk factors in an area with suspected cancer cluster in Egypt. Z.U.M.J; 20(1).
2. Baris D, Silverman DT, Brown LM, Swanson GM, and Hayes RB (2007): Occupation, pesticide exposure and risk of multiple myeloma. Environ Health; 30(3): 215-222.

3. Bigatão DA (2009): Cuidados e destinação final de embalagens, na utilização de agrotóxicos porprodutores rurais no município de Itaporä. M.S. Thesis, University of Brasília, Federal District, Brazil, 2009.

4. Bolognesi C (2003): Genotoxicity of pesticides: A review of human biomonitoring studies. Mutat Res; 543:251-272. [PubMed]

5. Burger J, Mol F, and Gerowitt B (2008): The 'necessary extent' of pesticide use-Thoughts about a key term in German pesticide policy. Crop Prot. 27:343-351.

6. Central Agricultural Pesticides Laboratory (2009): control measures of pesticide using in Egypt. Agriculture pesticide committee: Ministry of Agriculture and Land Reclamation. [http://www.apc.gov.eg/ar/products/showall. aspx webcite.

7. Chandler D, Davidson G, Grant WP, Greaves J, and Tatchell GM(2008): Microbial biopesticides for integrated crop management: An assessment of environmental and regulatory sustainability. Trends Food Sci Technol; 19:275-283.

8. Corriols M, Marin J, Berroteran J, Lozano LM, Lundberg I, and Thorn A (2008): The Nicaraguan pesticide poisoning register: constant underreporting. Int J Health Serv; 38(4):773-787.

9. Eleftherohorinos IG (2008): Weed Science: Weeds, Herbicides, Environment, and Methods for Weed Management. AgroTypos; Athens, Greece.Pp 76-80.

10. Environmental and protection agency (EPA) U.S (2012): Registering Pesticides.Available: online:http://www.epa.gov/pesticides/health/ emergency.htm .Last updated on 9/5/2012.

11. Forthofer RN, and Lee ES (1995): Introduction to biostatistics: A guide to design, analysis and 
discovery. Diego, USA: Academic Press.San 1995.

12. Gilden RC, Huffling K and Sattler B (2010): Pesticides and health risks. J Obstet Gynecol Neonatal Nurs; 39 (1): 103-10.

13. Hiluf K and Ayalew A (2015): Assessment of pesticide use, practice and environmental effects on the small holder farmers in the North Shoa zone of Amhara national regional state of Ethiopia. Research Journal of Agricultural and Environmental Sciences. 2 (2): 16-24, Available online at www.rjaes.com.

14. Ibitayo O (2006): Egyptian Farmers' Attitudes and Behaviors Regarding Agricultural Pesticides: Implications for Pesticide Risk Communication. Risk Anal. 26:989-995. PubMed Abstract I Publisher Full Text

15. IBM (2010): IBM SPSS Statistics 19 Core System Users' Guide. SPSS Inc, Chicago [http:// www.IBM-SPSSStatistics- User_s-Guide.pdf].

16. Jeyaratnam J (2000): Acute pesticide poisoning: a major global health problem. World Health Stat Q; 43 (3): 139-44. PMID 2238694.

17. Karabelas AJ, Plakas KV, Solomou ES, Drossou V, and Sarigiannis, DA (2009): Impact of European legislation on marketed pesticides-A view from the standpoint of health impact assessment studies. Environ Int; 35, 1096-1107.

18. Kimani VN and Mwanthi AM (1995): Agrochemical exposure and health implications in Githunguri location - Kenya. East Afr Med J; 72(8):531-535.

19. Martínez-Valenzuela C, Gómez-Arroyo S, Villalobos-Pietrini R, Waliszewski S, CalderónSegura ME, Félix-Gastélum R, and ÁlvarezTorres A (2009): Genotoxic biomonitoring of agricultural workers exposed to pesticides in the north of Sinaloa State, Mexico. Environ Int; 35:1155-1159. [PubMed]

20. Mekonnen Y, Agonafir T (2002): Pesticide sprayers' knowledge, attitude and practice of pesticide use on agricultural farms of Ethiopia.
Occup Med; 52:311-315.

21. Miligi L, Costantini AS, Veraldi A, Benvenuti A, WILL, and Vineis P (2006): Cancer and pesticides: an overview and some results of the Italian multicenter case-control study on hematolymphopoietic malignancies. A N Y Acad Sci. 1076: 366-77 [ Links ]

22. Miller GT (2004): Living in the Environment (12th Ed.). Belmont: Wadsworth/Thomson Learning. ISBN 0-534-37697-5

23. Murphy HH, Hoan NP, Matteson P, and Abubakar AL (2002): Farmers' self-surveillance of pesticide poisoning: a 12-month pilot in northern Vietnam. Int J Occup Environ Health; 8(3):201-211.

24. Nazaril MR, Bin HJ, and Hassan S (2011): The role of television in the enhancement of farmers' agricultural knowledge. AJAR; 6:931-936.

25. Ngowi, AV, Maeda DN, and Partanen TJ (2002): Knowledge, attitudes and practices (KAP) among agricultural extension workers concerning the reduction of the adverse impact of pesticides in agricultural areas in Tanzania. Med Lav; 93: 338-346.

26. Ngowia AVF, Mbisea TJ, Ijania ASM, Londonb L, and Ajayic OC (2007): Smallholder vegetable farmers in Northern Tanzania: pesticides use practices, perceptions, cost and health effects. Crop Prot; 26:1617-1624. PubMed Abstract I Publisher Full Text I PubMed Central Full Text

27. Nwilene FE, Nwanze KF, and Youdeowei A (2008): Impact of integrated pest management on food and horticultural crops in Africa. Entomol Exp Appl; 128:355-363.

28. Pasiani J, Torres P, Silva J, Diniz B and Caldas E (2012): Knowledge, Attitudes, Practices and Biomonitoring of Farmers and Residents Exposed to Pesticides in Brazil. Int J Environ Res Public Health; 9: 3051-3068; doi: 10.3390/ ijerph9093051.

29. Pimentel D, Acquay H, Biltonen M, Rice P, and Silva M (2011): Environmental and Economic 
Costs of Pesticide Use. BioScience 42.10 (1992): 750-60., [1]. Retrieved on February 25, 2011.

30. Recena MCP, Caldas ED, Pires DX, and Pontes ERJ (2006): Pesticides exposure in Culturama, Brazil-Knowledge, attitudes and practices. Environ Res; 102: 230-236.

31. Rucker M (2004): Attitude and clothing practices of pesticide applicators. In Protective Clothing Systems and Materials. Edited by Mastura R. New York: Marcel Dekker. 81.

32. Sanborn M, Kerr KJ, Sanin LH, Cole DC, Bassil KL, and Vakil C (2007): "Non-cancer health effects of pesticides: Systematic review and implications for family doctors". Can Fam Physician; 53 (10): 1712-20. PMC 2231436. PMID 17934035.

33. Silva JM, Novato-Silva E, Faria HP, and Pinheiro TMM (2005): Pesticides and work: A dangerous combination for the Brazilian agricultural worker's health. Ciênc Saúde Col; 10: 891-903.

34. Sivayoganathan C, Gnanachandran S, Lewis J, and Fernando M (1995): Protective measure use and symptoms among agro pesticide applicators in Sri Lanka. Soc Sci, 40:431-436. PubMed Abstract I Publisher Full Text

35. Tchounwou PB, Ashour BA, Moreland-Young C, Ragheb DA, Romeh AA, and El-Adarosy
G (2002): Health risk assessment of pesticide usage in Menia El-Kamh Province of Sharkia Governorate in Egypt. Int J Mol Sci; 3:10821094. Publisher Full Text

36. Tsakiris IN, Danis TG, Stratis IA, Nikitovic N, Dialyna IA, Alegakis AK, and Tsatsakis AM (2004): Monitoring of pesticide residues in fresh peaches produced under conventional and integrated crop management cultivation. Food Addit Contam; 21: 670-677.

37. United Nations Environmental Program (UNEP) (2009): Risk profile on Endosulfan: Report Adopted by the Persistent Organic Pollutants Review Committee at its Fifth Meeting (UNEP/ POPS/POPRC.5/10/Add.2). Geneva: 2009.

38. Way MJ, and Van Emden HF (2000): Integrated pest management in practice-pathways towards successful application. Crop Prot; 19:81-103.

39. Williamson S, Ball A, and Pretty J (2008): Trends in pesticide use and drivers for safer pest management in four African countries. Crop Prot; 27:1327-1334. Publisher Full Text

40. Yassin MM, Abu Mourad TA, and Safi JM (2002): Knowledge, attitude, practice, and toxicity symptoms associated with pesticide use among farm workers in the Gaza Strip. Occup Environ Med; 59:387-393. [PMC free article] [PubMed] 